\title{
Identification of Competitiveness Variable for Manufacturing Industries with SEM Model Approach
}

\author{
Lukmandono*, Minto Basuki and Jaka Purnama \\ Department of Industrial Engineering, Adhi Tama Institute of Technology Surabaya, Arif Rahman Hakim Street Number 100 Surabaya 60117 , East Java, Indonesia
}

\begin{abstract}
Competitiveness increasing for manufacturing industry needs to get attention because it is one of the main sectors driving economic growth. This study aims to determine the variables forming the competitiveness of the manufacturing industry and create a model of structural equations. The approach used is the SEM model that is able to analyze the relationship patterns among the variables used in the model. The results show that all constructs used in confirmatory factor analysis have fulfilled the predetermined goodness of fit. The probability value of the goodness of fit test shows the value of 0.071 with the feasibility tests of the eligible model as a good model. Thus, the suitability of the model predicted by the observed values adequately satisfies the model's suitability. This shows that simultaneously the influence for target of development variables to manufacturing industry and manufacturing industry characteristic variable to model of industrial competitiveness development is $20.1 \%$.
\end{abstract}

Keywords: Competitiveness; Manufacturing industry; SEM; Confirmatory analysis; Godness of model test

\section{Introduction}

The World Economic Forum [1] defines competitiveness as a condition of institutions, policies, and factors that determine the level of economic productivity of a country. High productivity reflects high competitiveness, and high competitiveness has the potential to enable high economic growth, which will further improve the welfare of the population. The issue of industrial competitiveness is always associated with competitive strategy [2]. A competitive advantage arises when a company can produce the same product that its competitors produce at a lower cost as cost advantage, or produce different and better products/ services produced by competitors as differentiation advantage.

The competitiveness of a nation is determined by the competitiveness of the development actors or the business actors, the competitiveness of their communities and the competitiveness of the state. The competitiveness of enterprises means the ability of companies to compete [3]. The company has its own strategy to lower costs, improve product quality, and gain network marketing. Industrial development requires increased competitiveness in both domestic and international markets [4].

Companies need to deploy two forces of competitiveness as well as to compete. First, comparative advantage, attached to the low costs of factors of production, such as labor, raw materials, capital or physical infrastructure, and scale of business. Second, competitive advantage, which is in the ability of creativity, productivity, and innovation that includes technological innovation, marketing innovation, product position innovation among competitor's products, and service quality innovation. The strength of competitiveness that relies on comparative advantage is a strength that is merely physical or tangible. Meanwhile, the power of competitive competitiveness is the strength of intangible competitiveness.

Avella et al [5] and Miltenburg [6] emphasized the importance of manufacturing strategy as a determinant of corporate competitiveness. The four competitive key manufactures used are cost, quality, delivery and flexibility. Sohn et al. [7] conducted a study on 246 respondents using Maximum Likelihood Estimation (MLE), and Partial Least Square (PLS) with structural equation model to evaluate R\&D performance through three aspects: output, outcome and impact given by adopting the MBNQA criterion (Malcolm Baldrige National Quality Award).

Research in the field of industrial competitiveness, especially manufacturing industry has been done by many researchers from various countries. These studies are generally focused on the problems associated with the influence of several variables on the performance of the company. The competitiveness of the industry is described as a level of performance with an overall indicator of customer, satisfaction and market performance. The influencing variables are technology and strategy interaction and competitive capabilities [8].

In another study, industry competitiveness is described as firm performance measured through market share and sales growth. Two influencing variables are competitive strategy and manufacturing strategy [9]. This model confirms that there is a relationship between competitive strategy and manufacturing strategy to firm performance firm. In general, the competitive strategy used in this model believes that a company can only create higher value for customers at high cost or create a fair value at a lower cost. Conversely, companies that seek to create blue oceans pursue differentiation and low cost simultaneously [10].

The purpose of this study is to determine the variables that affect the competitiveness of the manufacturing industry and create a model of structural equations through the SEM approach. The results of this study are expected to provide input for industry players about the determinant variables that affect the competitiveness of the manufacturing industry so as to increase the potential competitiveness. With the model produced in the research industry actors can also make

*Corresponding author: Lukmandono, Department of Industrial Engineering Adhi Tama Institute of Technology Surabaya, Arif Rahman Hakim Street Number 100 Surabaya 60117, East Java, Indonesia, Tel: 0315994620; E-mail: lukmandono@itats.ac.id

Received February 28, 2018; Accepted March 21, 2018; Published March 27 2018

Citation: Lukmandono, Basuki M, Purnama J (2018) Identification of Competitiveness Variable for Manufacturing Industries with SEM Model Approach. Ind Eng Manage 7: 252. doi:10.4172/2169-0316.1000252

Copyright: (c) 2018 Lukmandono, et al. This is an open-access article distributed under the terms of the Creative Commons Attribution License, which permits unrestricted use, distribution, and reproduction in any medium, provided the original author and source are credited. 
the development of manufacturing industry in the region based on various indicators generated in this model.

\section{Literature Study: Competitiveness Analysis of Manufacturing Industry}

The manufacturing industry is the main sector driving economic growth, contributing almost 30 percent to gross domestic product (GDP). In addition to the large share of exports in the manufacturing industry, the absorption of manpower in the manufacturing industry also ranks above so that the performance of the manufacturing sector will have a real impact on exports, labor absorption as well as the overall economy (BPS, 2010). Increased competitiveness, especially the competitiveness of the manufacturing industry should continue to be pursued, in order to increase industrial growth more easily achieved.

The four competitive key manufactures that include cost, quality, delivery and flexibility show the importance of manufacturing strategy as a determinant of corporate competitiveness [11]. The existence of manufacturing strategy also contributes to enhance the competitiveness of enterprises [12]. Porter's value chain model is used to prove that there is a relationship between knowledge management activities and competitiveness. The Porter's value chain model illustrates the role of each activity towards increasing value added for the organization to enhance competitiveness through increased productivity, agility, reputation and innovation [13].

In order to support the strengthening of the competitiveness of the manufacturing industry it is necessary to develop a competitive model capable of identifying the variables that affect its competitiveness. The fundamental difference of this study with other research is the use of modeling variables and their methods of completion. The settlement method used to create flowcharts is a structural equation model (SEM). This model can be used as a basis for planning the development strategy of the manufacturing industry.

\section{Determination of Thinking Framework and Dimensional Variables}

Based on the study of the theory that has been done to produce a research flow to solve the problem. The existing problem is how to determine the variables that affect the competitiveness of the manufacturing industry. The framework of thinking generates the concept of developing the research model.

The causality relationship in Figure 1 shows that the model of developing industrial competitiveness is influenced by industrial development goals and industry characteristics. The hypothesis of the concept of the development of this model can be written as H1: Causality between industry characteristics and the model of development of industrial competitiveness.

The target variable of industrial development is determined by three indicators, namely: (1) growth in the number of industries, (2) export growth, and (3) labor growth. Industry characteristic variable is determined by four indicators, namely: (1) investment value, (2) value of production capacity, (3) value of labor characteristic, and (4) marketing value. Variable models of industrial competitiveness development are determined by five indicators: (1) technology, (2) industrial markets, (3) partnerships, (4) manufacturing strategies, and (5) competitive strategies.

\section{Preparation of measuring instruments}

The measuring tool used is a questionnaire that reflects the performance of latent variables through its indicators. This questionnaire is used to determine the effect of industry target development variables and industry characteristics on the model of industrial competitiveness development. The number of respondents used is 160 respondents manufacturing industry. Respondents who fill out the questionnaires come from elements of government and business actors in the field of manufacturing industry. With estimation models using maximum likelihood (ML), the minimum required sample size is 100 [14]. The SEM method is the preferred method for obtaining structural models that can be used for predictive purposes. This is because the SEM method can test the relationship of causality, validity and reliability. SEM can also be used for recursive and reciprocal models, and their outputs are determinants, structural models and measurement models [14]

\section{Structural equation modeling analysis}

The model development uses theoretical framework that the manufacturing industry competitiveness model is determined by two latent variables namely industrial development target and manufacturing industry characteristic. Based on the framework, a model framework is constructed using several indicators. The objective of developing the manufacturing industry is to use 3 indicators, as: (1) perception index of growth plan of manufacturing industry, (2) growth plan of marketing and export of manufacturing industry, and (3) growth plan in manufacturing industry contribution.

Characteristics of the manufacturing industry use four indicators, namely: (1) the investment value of the manufacturing industry, (2) the manufacturing production capacity, (3) the manufacturing industry, and (4) the manufacturing industry. While the model of developing the competitiveness of the manufacturing industry uses 5 indicators, namely: (1) indicators of manufacturing technology perception index in the model, (2) indicators of manufacturing industry perception index in the model, (3) indicators of partnership perception index in the model, perceptual index of manufacturing strategy in the model, and (5) perceptual index indicators of competing strategies in the model. The theoretical framework of all variables is then described in the form of flowcharts in Figure 2.

The flow diagram in Figure 2 is then converted into equations for confirmatory factor analysis and model structure. The equations for the confirmatory factor analysis are as follows:

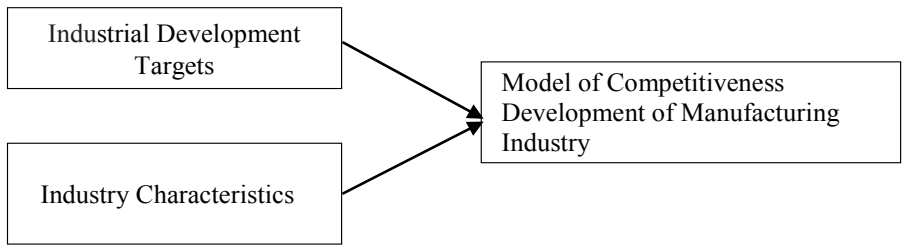

Figure 1: Concept development of research model. 


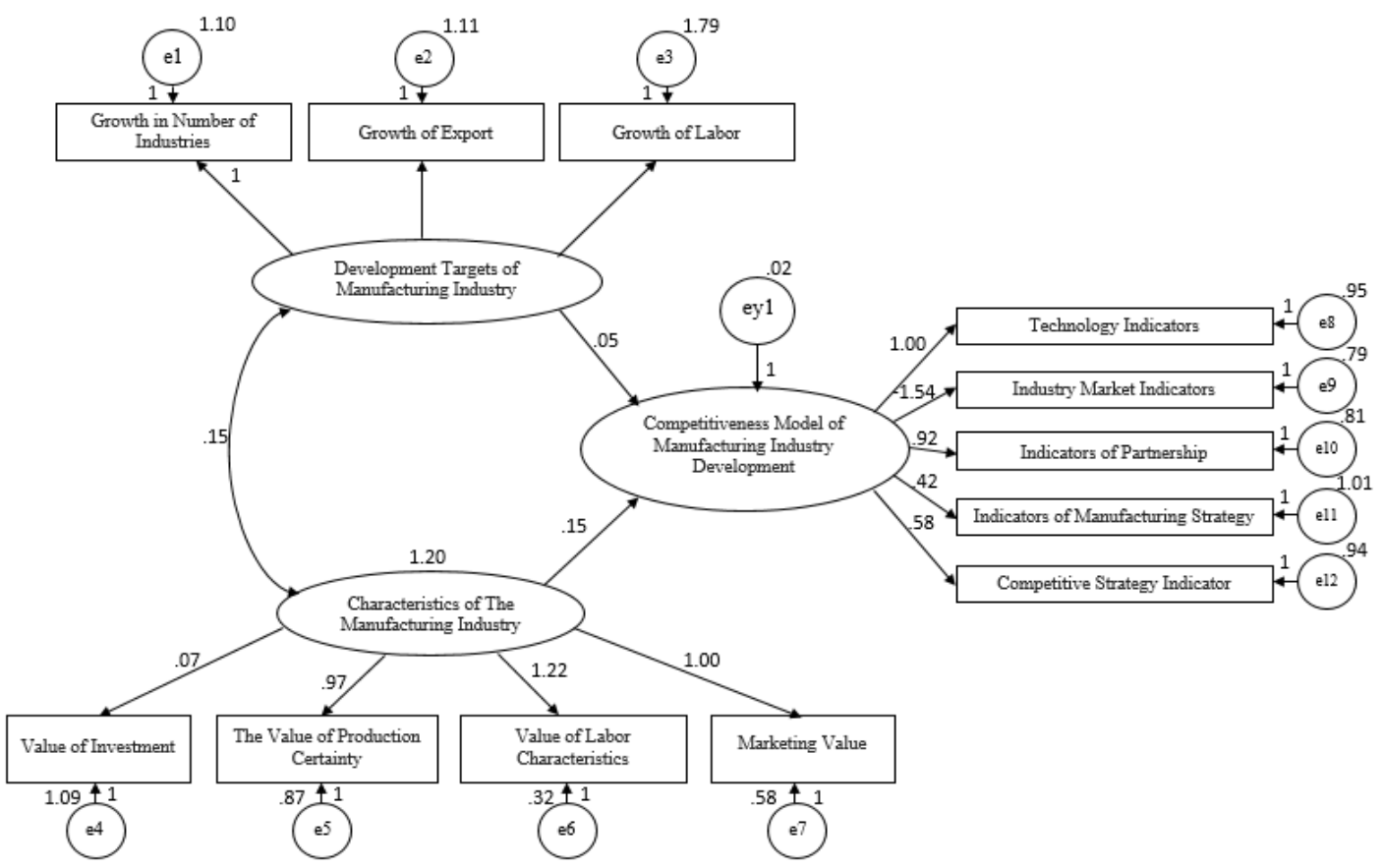

Figure 2: Flow Chart of manufacture competitiveness model.

Growth Plan Number $=\lambda$ The Industrial Development Goals of of Industries Manufacturing+el

Marketing and Export $=\lambda$ The Industrial Development Goals of Growth Plan Manufacturing+e2

Growth Plan

Employment

$=\lambda$ The Industrial Development Goals of Manufacturing+e3

Investment Value $\quad=\lambda$ Characteristics Manufacturing Industry+e4

Production Capacity $=\lambda$ The Manufacturing Industry Characteristics+e5

Amount of Labor $\quad=\lambda$ Characteristics of Manufacturing Industry+e6

Marketing Value $\quad=\lambda$ The Manufacturing Industry Characteristics+e7

Technology Indicator $=\lambda$ Model Competitiveness Development Industry $+\mathrm{e} 8$

Market Indicator $\quad=\lambda$ Model Competitiveness Development

Industry Industry+e9

Partnership Indicator $=\lambda$ Model Competitiveness Manufacturing Industry+e10

Manufacturing

$=\lambda$ Model Competitiveness Development Model $+\mathrm{e} 11$

Strategy Indicator

Competitive Strategy $=\lambda$ Model Competitiveness Development Model $+\mathrm{e} 12$ Indicator

\section{Equations for model structure}

Model Development of Industrial Competitiveness of Manufacturing $=\beta 1$ Target of Manufacturing Industry Development $+\beta 2$ Characteristics of Manufacturing Industry+ey1.

Input data used in this research is the result of the conversion of questionnaires into the scale of perception with sample size 160 and data processing using computer program AMOS 16 with maximum likelihood estimation. The results of running model diagram of manufacturing industry flow shown in Figure 3.

\section{Goodness of fit model test}

Confirmatory analysis results show good condition because all criteria of measurement index required in the model have been fulfilled. Comparison of criteria of measurement index and model results is shown in Table 1. From the table it is seen that all constructs used to form a research model, on confirmatory factor analysis have fulfilled the predetermined goodness of fit. The probability value of goodness of fit test shows a value of 0.071 , with feasibility tests of the model that qualify as a good model. Thus, the suitability of the model predicted by the observed values adequately satisfies the model's suitability.

After all goodness of fit value of model of manufacturing industry fulfilled, then conducted hypothesis testing based on critical ratio value (CR) from a causality relation from result of SEM processing. $\mathrm{H}_{1}$ : causality between the objectives of developing a manufacturing industry with a model of developing the competitiveness of the manufacturing industry and $\mathrm{H}_{2}$ : causality between the characteristics of the manufacturing industry and the model of developing the competitiveness of the manufacturing industry.

The estimation parameter for testing the influence of manufacturing industry development targets on the manufacturing competitiveness development model shows a value of 2.31 and with a probability of 0.0462. Both values obtained are eligible for $\mathrm{H}_{1}$ acceptance i.e., $\mathrm{CR}$ values greater than 1.96 and probabilities smaller than 0.05 . Thus it can be concluded that the target of developing the manufacturing industry will affect the model of developing the competitiveness of the manufacturing industry.

The estimation parameter for testing the influence of the characteristics of the manufacturing industry with the model of developing the competitiveness of the manufacturing industry shows a value of 1.978 and with a probability of 0.0356 . Both values obtained are eligible for $\mathrm{H} 2$ acceptance i.e., $\mathrm{CR}$ values greater than 1.96 and 
Citation: Lukmandono, Basuki M, Purnama J (2018) Identification of Competitiveness Variable for Manufacturing Industries with SEM Model Approach. Ind Eng Manage 7: 252. doi:10.4172/2169-0316.1000252

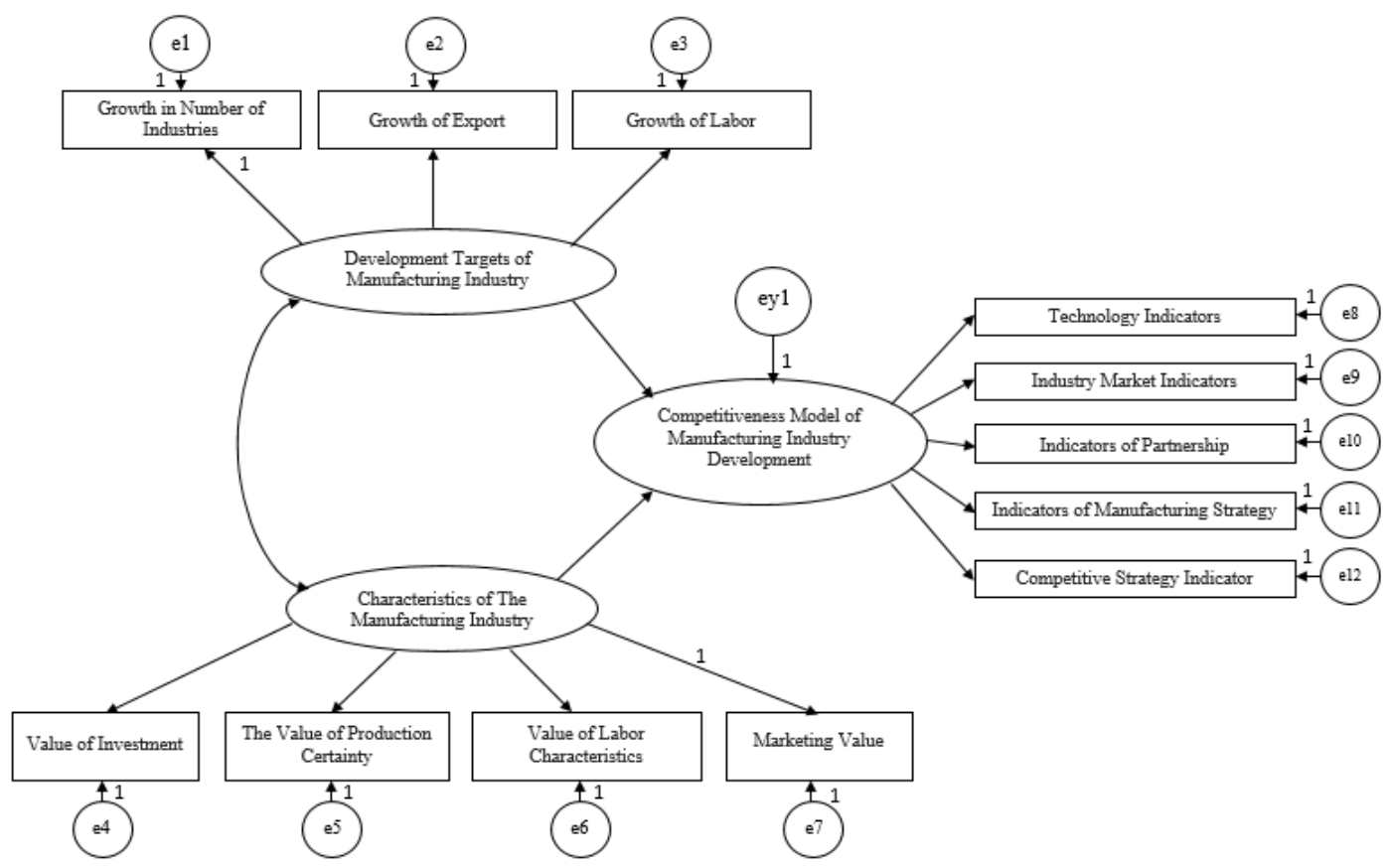

Figure 3: Result of confirmatory analysis for manufacturing industry models.

\begin{tabular}{|c|c|c|}
\hline Indicator Index Criteria & Reference Value & Model Result \\
\hline Chi square statistic & As small as possible \\
\hline p-value & $\geq 0.525$ \\
\hline CMIN/df & $\leq 2.00$ \\
\hline RMSEA & $\leq 0.08$ \\
\hline GFI & Approaching 1 \\
\hline AGFI & Approaching 1 \\
\hline TLI & Approaching 1 \\
\hline CFI & Approaching 1 \\
\hline
\end{tabular}

Table 1: Goodness of fit model data manufacturing industry.

Model of Competitiveness Company Industry Manufacturing Model of Competitiveness Company Industry Manufacturing $\mathrm{x} 11$ (growth in the number of industries)

$\mathrm{x} 12$ (export growth)

x13 (labor growth)

x24 (marketing value)

x23 (characteristic value of labor)

x22 (value of production capacity)

$\mathrm{x} 21$ (investment value)

y1 (technological indicator)

y2 (industry market indicator)

y3 (partnership indicator)

y4 (indicator of manufacturing strategy)

y5 (competitive strategy indicator)

\begin{tabular}{l|l|l|} 
& & Estimate \\
$\leftarrow$ & Developing Targets of Manufacturing Industry & 0.052 \\
$\leftarrow$ & Manufacturing Industry Characteristic & 0.149 \\
\hline & Targets Developers Manufacturing & 1.000 \\
\hline & Targets Developers Manufacturing & 1.089 \\
$\leftarrow$ & Targets Developers Manufacturing & 0.678 \\
$\leftarrow$ & Characteristics of Manufacturing Industry & 1.000 \\
\hline & Characteristics of Manufacturing Industry & 1.219 \\
$\leftarrow$ & Characteristics of Manufacturing Industry & 0.972 \\
$\leftarrow$ & Industrial Competitiveness Development Model & 0.071 \\
\hline & Industrial Competitiveness Development Model & 1.000 \\
\hline & Industrial Competitiveness Development Model & -1.536 \\
$\leftarrow$ & Industrial Competitiveness Development Model & 0.925 \\
$\leftarrow$ & Industrial Competitiveness Development Model & 0.424 \\
\hline
\end{tabular}

Table 2: Regression weight manufacture industry.

probabilities smaller than 0.05 . Thus it can be concluded that the characteristics of the manufacturing industry will affect the model development of the competitiveness of manufacturing industries.

\section{Interpretation of manufacture competitiveness model}

The measurement model of the confirmatory factor analysis is a modeling process directed to investigate the existing indicators being perfectly capable of defining a construct. From Table 2 it can be seen that industry market indicator is unable to define construct model of competitiveness development of manufacture industry because its value is -1.536 . Therefore, the indicators to be used in the manufacturing industry competitiveness development model are technological 
Citation: Lukmandono, Basuki M, Purnama J (2018) Identification of Competitiveness Variable for Manufacturing Industries with SEM Model Approach. Ind Eng Manage 7: 252. doi:10.4172/2169-0316.1000252

Page 5 of 5

indicators of value 1, 0.925 partnership indicators, 0.424 manufacturing strategy indicators, and 0.583 competitive strategy indicator. The result of regression weight also shows that the direct influence of the target of manufacturing industry development on the manufacturing industry competitiveness development model is 0.052 . While the direct influence of the characteristics of the manufacturing industry on the development model of manufacturing industry competitiveness of 0.149. In the form of equations for confirmatory analysis, the effects of the latent variables on the model of developing the competitiveness of the manufacturing industry are:

$$
\begin{array}{lrl}
\begin{array}{l}
\text { Model Development of } \\
\text { Industrial Competitiveness of }
\end{array} & \begin{array}{l}
\beta 1 \text { Target of Manufacturing Industry } \\
\text { Mevelopment }+\beta 2 \text { Characteristics of } \\
\text { Manufacturing }
\end{array} \\
& \text { Manufacturing Industry+ey1 } \\
= & 0.052+0.149+\text { ey1 } \\
= & 0.201+\text { ey1 }
\end{array}
$$

This shows that simultaneously the influence of target variable of development of manufacturing industry and manufacturing industry characteristic variable to model of industrial competitiveness development is $20.1 \%$.

\section{Conclusion}

From the results of this study can be concluded that the model of structural equation of manufacturing industry competitiveness is formed from two variables, namely the target of industrial development and industry characteristics. With probability value of goodness of fit test that has fulfilled the minimum limit of 0.05 on the measurement of confirmatory analysis, the proposed industry competitiveness model has been able to define the constructor of the variable of competitiveness. Thus, technology indicators, partnerships, manufacturing strategies and competitive strategies can be used as variables that affect the competitiveness of the manufacturing industry.

\section{Acknowledgement}

Thanks to the Direktorat Riset dan Pengabdian Masyarakat (DRPM) who has supported and funded this paper through the grants of Excellence Research on Higher Education (PUPT) for the fiscal year 2017.

\section{References}

1. Badan Pusat Statistik Provinsi Jawa Timur (2011) Pertumbuhan Produks Industri Manufaktur Besardan Sedang Jawa Timur Triwulan I tahun. Berita Resmi Statistik No. 29/05/35/Th. IX, 2 Mei 2011.

2. Porter, Michael E (1990) On Competition, HBS Press.

3. Zuhal (2010) Knowledge \& Innovation Platform Kekuatan Daya Saing. Penerbit Gramedia Pustaka Utama.

4. Demeter K (2003) Manufacturing Strategy and Compepetitiveness. Int J Pres Ves Pip 81-82: 205-213.

5. Avella L, Fernandez E, Vazquez CJ (2001) Analysis of Manufacturing Strategy as an Explanatory Factor of Competitiveness in the Large Spanish Industrial Firm. Int J Prod Econ 72: 139-157.

6. Miltenburg $J(2008)$ Setting Manufacturing Strategy for a Factory within a factory. Int J Prod Econ 113: 307-3223.

7. Sohn SY, Joo YG, Han HK (2007) Structural Equation Model for the Evaluation of National Funding on R\&D Project of SMEs in Consideration with MBNQA Criteria. Eval Program Plann 30: 10-20.

8. Tracey M, Vonderembse MA, Lim J (1999) Manufacturing Technology and Strategy Formulation: Keys to Enhancing Competitiveness and Improving Performance. J Oper Manag 17: 411-428.

9. Gyampah KA, Acquaah M (2008) Manufacturing Strategy, Competitive Strategy and Firm Performance: An Empirical Study in a Developing Economy Environment. Int J Prod Econ 111: 575-592.

10. Kim WC, Mauborgne R (2009) Blue Ocean Strategy (Strategi Samudra Biru), Ciptakan Ruang Pasar Tanpa Pesaing dan Biarkan Kompetisi Tak Lagi Relevan. Harvard Business School Publishing Corporation.

11. Holsapple CW, Singh M (2001) The Knowledge Chain Model: Activities for Competitiveness. Expert Systems with Applications 20: 77-98.

12. Ghozali I (2008) Model Persamaan Struktural, Konsep dan Aplikasi dengan Program AMOS 16. Penerbit: Badan Penerbit Universitas Diponegoro, Semarang.

13. Nikolaou IE, Evangelinos KI (2010) A SWOT analysis of environmental management practices in Greek Mining and Mineral Industry. Resour Policy 35: 226-234.

14. Sirikrai SB, Tang JCS (2006) Industrial Competitiveness Analysis: Using the Analytic Hierarchy Process. J High Tech Manag Res 17: 71-83. 